\section{Sickle Cell Disease: Is Hydroxyurea the Final Answer?}

We read with interest the recent article on efficacy of hydroxyurea (HU) in sickle cell disease (SCD) [1]. We share our experience in managing nine such patients (4 males) aged between 3 and 19 years. Seven patients were on regular HU therapy $(15-20 \mathrm{mg} / \mathrm{kg} / \mathrm{d})$ and penicillin prophylaxis for median period of 2.8 years. All had history of repeated fever, chest infections and vasoocclusive episodes before reporting to our center. Three children (all from Africa) underwent successful hematopoietic stem cell transplant (HSCT).

Two Indian compound heterozygous SCD patients are doing well on hydroxyurea $(15 \mathrm{mg} / \mathrm{kg})$ for last one year and doing fine. A 13-year-old Indian girl is also on hydroxyurea for last 6 years. Another 5-year-old Indian girl presented initially with acquired pure red cell aplasia due to parvovirus that subsequently was diagnosed as compound heterozygous SCD. This patient is doing well on $\mathrm{HU}(20 \mathrm{mg} / \mathrm{kg} / \mathrm{d})$ for last 4 years. All these patients had marked reduction in the vaso-occlusive episodes. A 2-year-old African boy on hydroxyurea, is due for his transplant. A 16-yr-old African girl who was on HU for last 4 years developed stroke with loss of speech and hemiparesis. She had complete recovery after packed cell transfusion and is doing well on regular red cell transfusions. Possibly Indian patients with SCD have less severe form than African population, and thus can be managed by lower dose of $\mathrm{HU}(10 \mathrm{mg} / \mathrm{kg} /$ day $)$ as shown by Jain, et al. [1]. However, optimum dose of HU in these populations still needs to be determined.

The long-term safety profile of hydroxyurea in children with SCD is less well characterized. Hydroxyurea is genotoxic in a wide range of test systems and is thus presumed to be a human carcinogen [2]. In patients receiving long-term hydroxyurea for myeloproliferative disorders, such as polycythemia vera and thrombocythemia, secondary leukemia has been reported [3]. Malignancies, including acute myeloblastic leukemia, acute lymphoblastic leukemia and Hodgkins lymphoma, have been reported occasionally in children with SCD treated with HU [4]. It is not fully known whether this leukemogenic effect is secondary to hydroxyurea or is associated with the patient's underlying disease. Recently, abnormal sperm parameters have been reported in adult males with SCD who were on HU therapy [5].

With increasing use of hydroxyurea in young children with SCD, it will be prudent to monitories its long-term safety profile. HSCT remains the only curative option.

\section{Mohammed Ramzan and Satya P Yadav Pediatric Hematology Oncology and Bone Marrow Transplant Unit, Fortis Memorial Research Institute, Gurgaon, Haryana, India satya_1026@hotmail.com}

\section{REFERENCES}

1. Jain DL, Apte M, Colah R, Sarathi V, Desai S, Gokhale A, et al. Efficacy of fixed low dose hydroxyurea in Indian children with sickle cell anemia: A single center experience. Indian Pediar. 2013;50:929-33.

2. Khayat AS, Antunes LM, Guimaraes AC, Bahio MO, Lemos JA, Cabral IR, et al. Cytotoxic and genotoxic monitoring of sickle cell anemia patients treated with hydroxyurea. Clin Exp Med. 2006;6:33-7.

3. Weinfeld A, Swolin B, Westin J. Acute leukaemia after hydroxyurea therapy in polycythaemia vera and allied disorders: prospective study of efficacy and leukaemogenicity with therapeutic implications. Eur J Haematol. 1994;52:134-9.

4. Couronné L, Schneider P, Montalembert M, Dumesnil C, Lahary A, Vannier JP. Hodgkin lymphoma in a sickle cell anaemia child treated with hydroxyurea. Ann Hematol. 2009; 88:597-8.

5. Berthaut I, Guignedoux G, Kirsch-Noir F, Larouziere VD, Ravel C, Bachir D, et al. Influence of sickle cell disease and treatment with hydroxyurea on sperm parameters and fertility of human males. Hematologica. 2008;93:988- 93. 